
SWPS 2017-17 (September)

\title{
Towards a Typology of Intermediaries in Transitions: a Systematic Review
}

\author{
Paula Kivimaa, Wouter Boon, \\ Sampsa Hyysalo and Laurens Klerkx
}

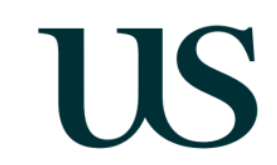




\section{SPRU Working Paper Series (ISSN 2057-6668)}

The SPRU Working Paper Series aims to accelerate the public availability of the research undertaken by SPRU-associated people, and other research that is of considerable interest within SPRU, providing access to early copies of SPRU research.

\section{Editors}

Tommaso Ciarli

Daniele Rotolo

Associate Editors
Karoline Rogge
Paul Nightingale,
Ben Martin, \&
Ohid Yaqub
Tommaso Ciarli
Joe Tidd \&
Carlos Sato
Maria Savona
Andrew Stirling
Caitriona McLeish
Editorial Assistance
Martha Bloom

\section{Contact}

T.Ciarli@sussex.ac.uk

D.Rotolo@sussex.ac.uk

\author{
Area \\ Energy \\ Science, \& Technology Policy \\ Development \\ Technology Innovation Management \\ Economics of Technological Change \\ Transitions \\ Civil Military Interface \\ K.Rogge@sussex.ac.uk \\ P.Nightingale@sussex.ac.uk \\ B.Martin@sussex.ac.uk \\ O.Yaqub@sussex.ac.uk \\ T.Ciarli@sussex.ac.uk \\ J.Tidd@sussex.ac.uk \\ C.E.Y.Sato@sussex.ac.uk \\ M.Savona@sussex.ac.uk \\ A.C.Stirling@sussex.ac.uk \\ C.A.McLeish@sussex.ac.uk
}

\section{Guidelines for authors}

Papers should be submitted to swps@sussex.ac.uk as a PDF or Word file. The first page should include: title, abstract, keywords, and authors' names and affiliations. The paper will be considered for publication by an Associate Editor, who may ask two referees to provide a light review. We aim to send referee reports within three weeks from submission. Authors may be requested to submit a revised version of the paper with a reply to the referees' comments to swps@sussex.ac.uk. The Editors make the final decision on the inclusion of the paper in the series. When submitting, the authors should indicate if the paper has already undergone peer-review (in other series, journals, or books), in which case the Editors may decide to skip the review process. Once the paper is included in the SWPS, the authors maintain the copyright.

\section{Websites}

UoS: www.sussex.ac.uk/spru/research/swps

SSRN: http://www.ssrn.com/link/SPRU-RES.html

IDEAS: ideas.repec.org/s/sru/ssewps.html

Research Gate: www.researchgate.net/journal/2057-6668_SPRU_Working_Paper_Series 


\title{
Towards a Typology of Intermediaries in Transitions: A Systematic Review
}

\author{
Paula Kivimaa $^{\mathrm{a}}$, Wouter Boon ${ }^{\mathrm{b}}$, Sampsa Hyysalo ${ }^{\mathrm{c}}$, Laurens Klerkx ${ }^{\mathrm{d}}$
}

\begin{abstract}
Intermediary actors have been proposed as key catalysts that speed up change towards more sustainable socio-technical systems. Research on this topic has gradually gained traction since 2009, but has been complicated by the inconsistency regarding what intermediaries are in the context of such transitions and which activities they focus on, or should focus on. This paper aims to bring more clarity to the topic of intermediaries in transitions, providing a typology that, beyond functions of intermediaries, is sensitive to different levels and phases of transitions, and the origin and emergence of intermediary actors. Based on a systematic review of academic scholarly articles, the paper identifies five different categories of intermediary actors that play a role in transitions based on their level of operation and origin, being insider/outsider, the level of agency, and the degree of neutrality. Some intermediaries are specifically set up to facilitate transitions, while others grow into the role of an intermediary during the process of sociotechnical change. On the basis of the study we argue that systemic and niche intermediaries are most crucial forms of intermediary actors in transitions, which should be also considered in planning future innovation governance frameworks. The paper further elaborates how intermediation occurs in pre-development, take-off, acceleration and embedding, and destabilisation phases. We note the lack of literature about intermediary activities in different phases of transition, in particular with respect to the acceleration and embedding phase. We, thus, suggest what kind of transition intermediaries are needed to better support the acceleration and embedding of innovations contributing to long-term sustainable development.
\end{abstract}

Key words: sustainability transitions, innovation intermediaries, phases of transition, multilevel perspective

\footnotetext{
${ }^{a}$ University of Sussex, UK \& Finnish Environment Institute SYKE

${ }^{\mathrm{b}}$ Utrecht University, Netherlands

${ }^{c}$ Aalto University School of Arts and Design, Finland

${ }^{\mathrm{d}}$ Knowledge, Technology and Innovation Group, Wageningen University, Netherlands
} 


\section{Introduction}

Intermediary actors have been proposed as key catalysts that speed up change towards more sustainable socio-technical systems (e.g. Hodson et al., 2013; Kivimaa, 2014), as part of sustainability transition policies or conversely in the absence of such policies (Wieczorek and Hekkert, 2012; Kivimaa and Kern, 2016). The transformation of sociotechnical systems is characterised by shifts in relations between actor groups, infrastructures, and between technologies and contexts of application. The resulting changing contexts and, consequently, changes in positions of and interlinkages between actors, increase the need for intermediary action (Van Lente et al., 2003; Moss, 2009).

With the exception of some early studies on transition intermediaries (van Lente et al., 2003, and Geels and Deuten, 2006), the theme has only recently gained traction in the sustainability transition field (Hodson and Marvin, 2009; Moss, 2009; Guy et al., 2010). Since 2009 much of this literature has focused on urban and energy contexts (e.g. Hodson and Marvin, 2009; Rohracher, 2009; Backhous, 2010). Studies using notions such as 'middle actors' (Parag and Yanda, 2014), 'hybrid actors' (Elzen et al., 2012) and 'boundary spanners' (Franks, 2010; Smink et al., 2015; Sternlieb et al., 2013; Tisenkopfs et al., 2015) have addressed intermediary-like functions. Furthermore, terms related to mediating space, such as 'user assemblages' (Nielsen, 2016) and 'interaction arenas' (Hyysalo et al., 2017; Hyysalo and Usenyuk, 2015) refer to intermediation for technologies in transition without explicitly mentioning intermediation.

This recent increase of articles on intermediaries in the sustainability transition literature recognises that they can be influential in transition processes, linking actors, activities, and sometimes even niche and regime levels (e.g. Kivimaa, 2014; White and Stirling, 2015; Fischer and Newig, 2016). This literature presents a wide range of interpretations of intermediaries, with varying levels of change agency (Kivimaa, 2014; Parag and Yanda, 2014), intent to drive sustainability transitions (e.g. Hodson and Marvin, 2009; Moss 2009) and normative positioning in transitions ranging from neutral to strongly advocating a certain position (e.g. Elzen et al. 2012; Orstavik, 2014). Early research on this topic, the communication of the concept and understanding its usefulness to transition scholars and stakeholders has struggled with inconsistencies regarding what sustainability transition intermediaries are and which activities they focus on, or should focus on. This is partly due to studies on intermediaries in sustainability transitions having very different starting points. Some studies (e.g. van Lente et al. 2003; Kivimaa, 2014) build on the considerable body of literature on innovation intermediaries that deals with systemic and network failures and dynamics of technology development (e.g. Bessant and Rush, 1995; Howells, 2006; Klerkx and Leeuwis, 2009; Katzy et al., 2013). Other intermediary studies are linked to research exploring how to organise urban governance when facing increasing sustainability pressures (e.g. Hamann and April, 2013; Hodson et al. 2013). We aim to bring more clarity to the topic of intermediaries in transitions, providing a typology that is sensitive to different phases of transitions, the origin of intermediaries, and processes intermediaries are engaged in. We argue that both academic and policy communities can benefit from this.

Informed by Petticrew and Roberts (2006), we systematically review literature on intermediaries in sustainability transitions and, on that basis, create a conceptual framework of intermediary types and processes in transition, highlighting key issues for future research and innovation policy. By engaging in such systemic review of literature, we elaborate:

1. How the literature has conceptualised transition intermediaries;

2. What the literature says about how intermediaries contribute to different levels on which transitions play out (niche, regime, niche-regime interaction); 
3. What the literature says about the origin of intermediaries and how intermediaries develop over time in the context of transitions; and

4. How intermediaries are linked to different phases of transitions?

Through answering these analytical questions, we create a tentative conceptual model of intermediation in sustainability transitions. We aim to produce a conceptual rather than empirical interpretation of the literature building on its gaps. We begin by creating a conceptual framework by connecting to the innovation intermediaries literature and summarising work on phases in sustainability transitions (Section 2) to guide our systematic review (Section 3). Our findings (Section 4) will highlight what intermediary processes may be necessary in different phases of transitions and how these processes link to empowering intermediaries, particularly in the context of innovation policy (Section 5), taking into account the origin of intermediaries and how their mandates develop and change over time. Furthermore, we intend to identify gaps in the analysis of intermediaries in transitions to inform future research.

\section{Conceptual framework}

\subsection{From innovation to transition intermediaries}

When new kinds of innovative goods enter markets, the institutions and organisations needed to make commodities exchangeable may not exist, and the form of those technologies is often not fully developed to meet the market demand (Williams et al. 2005). The various development and market functions required by the emerging new solutions to become accepted are henceforth handled otherwise, often by actors called 'innovation intermediaries' (Bessant and Rush, 1992; Howells, 2006). Howells (2006: 720) defined innovation intermediaries as "organization [s] or bod[ies] that act as agent [s] or broker[s] in any aspect of the innovation process between two or more parties. Such intermediary activities include: helping to provide information about potential collaborators; brokering a transaction between two or more parties; acting as a mediator, or go-between, bodies or organizations that are already collaborating; and helping find advice, funding and support for the innovation outcomes of such collaborations".

Innovation intermediaries may influence and support innovation in different ways. Indeed, much of the previous literature on innovation intermediaries has focused on their functions (e.g. Bessant and Rush, 1992; Howells, 2006). For example, innovation intermediaries can organise multi-actor networks consisting of businesses, citizens, academia and government for joint vision development; broker connections between consumers and technology providers for user-driven or user-informed innovation; and help innovating actors to access funding (Bessant and Rush, 1992, Howells, 2006; Stewart and Hyysalo 2008; Johnson, 2008; Boon et al, 2011; Polzin et al., 2016; Dedehayir et al., 2016; Kivimaa et al., 2017a). Following Den Hertog (2000), innovation intermediaries are, thus, ideally 'facilitators of innovation' who engage in network brokering and system (re-)configuring activities (Stewart and Hyysalo, 2008; Klerkx and Leeuwis, 2009). As such, they support innovation processes without necessarily being the originator of the new solution. Innovation intermediaries may influence, but cannot fully control, the design or use of the innovation outcomes, which sets them apart from other actors that are more aptly described as suppliers and users of new products or services (Stewart and Hyysalo, 2008). However, the literature shows that the role of 'facilitator' is often mixed with other roles in which the intermediary actively influences the form of the innovation and the flows between actors, e.g. by 'translating' knowledge from one domain to the other (Stewart \& Hyysalo, 2010; Klerkx and Leeuwis, 2009; Meyer, 2010). 
While Howells' definition suggests that innovation intermediaries are organisations, innovation intermediaries have been found to range from specific dedicated organisations to individuals within companies or public-sector organisations (Howells, 2006; Stewart and Hyysalo, 2008; Kivimaa, 2014) or collectives of individuals performing innovation intermediary functions, such as bottom-up peer support initiatives (Boon et al, 2011; Hyysalo et al. 2013). Innovation intermediation can be done more casually or as a dedicated activity. It has been observed that many innovation intermediaries intermediate as a side activity to their principal functions (e.g. technical consultancy, research, policy making, advocacy) rather than having this as their main source of revenue; legitimated by, for instance, prospects of future business opportunities or acquiring a societal mandate for change (Stewart and Hyysalo, 2008; Klerkx and Leeuwis, 2009; Hyysalo, 2010; Kivimaa, 2014). We argue that, instead of confining innovation intermediation only to certain specialised actors, such as technology transfer agencies (Macho-Stadler et al. 2007; Kivimaa et al., 2017a) or community energy initiatives (Barnes, 2016; Martiskainen 2016), it can be better understood as activities executed by diverse actors, only sometimes specialised in intermediation (cf. Bessant and Rush, 1992; Howells, 2006; Klerkx and Aarts, 2013).

A further corollary to the focus on intermediary activities rather than single or fixed actors is that innovation intermediaries in a given domain tend to form a dynamic ecology of intermediaries. Specific innovation intermediaries are likely to have differing competences, remits, and business models. This leads each into intermediating some aspects of novelty (but not others) (Stewart and Hyysalo, 2008). What follows is that different innovation intermediaries complement but also compete with each other, forming interdependencies and overlaps and sometimes also leaving gaps vis-à-vis a given innovation process or system. The resulting situation resembles a multilevel game where collaboration and competition, and formal and informal engagements between actors intertwine (Williams et al. 2005; Stewart and Hyysalo, 2008; Hyysalo, 2010; Klerkx and Aarts, 2013).

Innovation intermediaries have often been found to emerge in view of missing connections between actors or of high transaction costs for establishing and maintaining functional connections (e.g. Klerkx and Leeuwis, 2009) or in response to institutional changes or pressures (e.g. Kivimaa et al., 2017a). Their roles and the ecology of actors doing the intermediation are subject to evolution in the course of an innovation process and in the maturation of a technology area (e.g. Klerkx and Aarts, 2013). For example, the number of intermediary services in technology transfer have been noted to rise with overall expansion of technological markets (Lichtenthaler, 2013). Thus, intermediaries co-evolve with technological and institutional developments, taking different roles throughout transformative change.

We argue that, while in the context of transitions, innovation intermediaries can mobilise the traditional intermediary functions, such as transferring, processing and translating information, brokering between parties, and providing advice, they also go beyond these instrumental functions by being more engaged with systemic functions and directionality of change - even attempting to control it. Thus, we tentatively define 'transition intermediaries' as entities that intermediate for a sector (such as electricity, transport, or agriculture) or a region (such as city or even a country) to move towards new and more sustainable (or socially just) system configurations. This definition, thus, excludes those innovation intermediaries within a sector that mediate a new technology following path dependencies associated with the dominant regime (e.g. new carbon-based combustion engines in the energy sector) as well as those that are implicated by the transition but are not involved in the innovation or diffusion processes of novel technologies, products, or services, or creating institutional space for such to emerge.

In conclusion, innovation intermediaries serve systemic functions - such as facilitating multi-actor 
innovation networks, linking demand and supply side for disruptive innovations, connecting niche innovators to resources such as finance - which may also be transition-oriented. These functions are performed on different levels of aggregation, have different origins and may change during the course of a transition, which will be further elaborated through our conceptual literature review in the next subsection. In addition, to investigate the transition-enhancing nature of innovation intermediaries, their agency and normative position in view of the espoused vision and direction of sustainability transitions needs to be distinguished. This normative position is then again linked to the degree of neutrality they have in transition processes and actor networks connected to these.

\subsection{Multiple levels and niche-regime interaction in sustainability transitions}

The literature on sustainability transitions emerging in the new millennium has introduced a broader outlook on innovation, moving beyond product or process innovation to focus on broad systemic change. The key premise of the transition literature and its normative orientation is to study and promote sustainable transformative change, seen as a set of processes leading to fundamental shifts in sociotechnical systems and involving far-reaching modifications to technological, material, organisational, institutional, political, economic, and socio-cultural dimensions (Markard et al., 2012) with implications to innovation policy. The literature has evolved rapidly building on four key conceptual approaches: the multilevel perspective on socio-technical transitions, strategic niche management, transition management and technological innovation systems. However, the literature also goes beyond these four conceptualisations; several writings in this field make links to other concepts such as arenas for development, path dependence, path creation, urban transitions and many more. While we acknowledge the literature as a whole, in this paper, we zoom in on the levels (multi-layeredness) and phases (dynamics) of transitions in which intermediary activity occurs and intermediary actors are set up or emerge. We, therefore, take the multilevel perspective (Rip and Kemp, 1998; Geels, 2005) and the phases of transitions (Rotmans et al., 2001; Safarzynska et al. 2012; Van Lente et al. 2012) as the key conceptualisations to which we position the literature review findings about intermediaries in transition.

The multilevel perspective on socio-technical transitions (MLP) describes disruptive change in sociotechnical systems to occur through interplay between three levels, including micro-level spaces in which we can observe radical innovations (so called 'niches'), relatively stable and shared technologies, practices and institutions (regimes), and slow-moving developments in the exogenous environment (landscape) (Rip and Kemp, 1998; Geels, 2002). Associated and developing alongside the MLP has been the concept and literature of strategic niche management (Kemp et al., 1998; Hoogma et al., 2002) that assumes that innovations aimed at sustainability can be facilitated in the context of socio-technical experiments that take place in niches and are nurtured to effectuate systemic change.

The interaction between niches and regimes has been studied using different concepts (Ingram, 2015). Earlier studies looked at 'translation between niches and regimes' (Smith, 2007) as the dialectic process between niche action and regime response. Later, the processes that occur between the development of niches and their becoming of part of the regime - either new or incrementally transformed - have been elaborated by Smith and Raven (2012) as two types of empowerment. 'Fit-and-conform' empowerment implies a process through which low-carbon technologies become "competitive with mainstream sociotechnical practices in otherwise unchanged selection environments", not requiring far-reaching changes to institutions, infrastructures, skills and knowledge bases (Smith and Raven, 2012: 1030). The second type, 'stretch-and-transform' empowerment, more in line with niche-initiated transition, is regarded as a process through which mainstream selection environments are changed in a way (reframing and reforming institutions and rules) that makes them more agreeable for niche innovations that have emerged (Smith and Raven, 2012). More recent studies have explored agency in 'transitions in the 
making' studying the actions that actors employ to overcome barriers imposed by incumbent institutional structures in regimes (Farla et al., 2012; Fuenfschilling and Truffer, 2013), which has also been referred to as a process of 'anchoring' niches (Elzen et al., 2012). Here boundary spanning actors or intermediaries between niche and regime have been found crucial (Elzen et al., 2012; Smink et al., 2015).

\subsection{Phases of sustainability transitions}

Sustainability transitions have been described as long-term changes, the whole transformation process typically taking decades. When a transition starts and when it will end is seldom explicitly addressed. Rotmans et al. (2001) conceptually depicted a transition to consist of four phases: pre-development, take-off, acceleration and stabilisation. These phases were elaborated on by van Lente et al. (2012) and Safarzynska et al. (2012), the former making some connection to intermediary activities, noting that the phases approach is an over-simplification of complex and non-linear of transition processes.

The pre-development and exploration phase is described as a dynamic equilibrium, where the status quo does not visibly change (Rotmans et al., 2001) but experimentation takes place (Safarzynska et al., 2012). Van Lente et al. (2012) describes this phase as a combination - and conflict - between eagerness to find out what is possible (articulation of societal needs) and reluctance to change existing configurations. In this context, experimentation that is typically defined as small-scale and temporary exploratory action (Kivimaa et al., 2017b) can relatively easily take place even in change-resistant sociotechnical regimes. Niche technologies are not yet perceived as a threat by regime actors (Kanger and Schot, 2016).

In the take-off phase, the process of change begins (Rotmans et al., 2001) and novel solutions (niches) start to build up (Safarzynska et al., 2012). Niche development moves from experimentation to other forms of nurturing and shielding niches (Smith and Raven, 2012), and strategic management of and agenda building around niches takes place. Change may still be slow due to existing sociotechnical configurations.

Take-off is followed by the acceleration and embedding phase, which can take different forms, as described above in reference to 'fit-and-conform' and 'stretch-and-transform' strategies. In this phase 'niches expand, attract more users, and become mainstream markets starting to compete with the incumbent regime' (Kanger and Schot, 2016: 600). This phase can be distinguished from take-off as structural changes become visible through an accumulation of socio-cultural, economic, ecological and institutional changes and collective learning and increasing returns take place (Rotmans et al., 2001; Safarzynska et al., 2012). Yet, it is not always clear when take-off is replaced by acceleration and embedding, and when sufficient reframing (Rosenbloom et al., 2016) or coalition building (Hess, 2016) occurs to be regarded as transforming a regime.

The stabilisation phase implies a decreasing speed of social change when a new dynamic equilibrium is reached (Rotmans et al., 2001) and 'a former niche has established itself as a new regime' (Kanger and Schot, 2016: 600). Incremental change occurs to benefit from economies of scale. This begins the cycle anew as experimentation in novel solutions commences again (Safarzynska et al., 2012). In reality, when different but connected sociotechnical systems change at different speeds, it may be difficult to know when stabilisation is reached.

The MLP and transition phases' literatures are interconnected, although this link has remained implicit. While the MLP literature has been less specific about phases of transition, Geels (2005) emphasised early phases being characterised by uncertainty and 'interpretive flexibility' around radical innovations. This corresponds to Rotmans et al. (2001) take-off phase. Safarzynska et al. (2012) have also elaborated 
on transition phases from the perspective of governance: "the effectiveness, i.e. success, of the diffusion and adoption of innovations may depend on the extent of lock-in and path dependence, which vary in different phases of transition" (Safarzynska et al., 2012). They also note that the notion of a multiphase transition puts emphasis on the timing of intervention in steering transitions. We interpret this to mean that the (required) activities, agency and normative position of intermediaries change in the different phases.

\subsection{Towards an analytical framework}

By assuming niche development as the starting point of transitions, the model of transition phases does not take into account different types of transition pathways (cf. Geels and Schot, 2007; Geels et al., 2016) where change can also originate from landscape or regime level inducements. In this, it also somewhat underplays the process of destabilisation (cf. Turnheim and Geels, 2012, 2013) that may either follow the acceleration and embedding of niches (acknowledged in the model), or precede it in cases where external shocks disrupt the system (ignored in the model) and pave the way for an era of niche pre-development or take off. Regime destabilisation has been defined as processes that disrupt incumbent (industrial) regimes through weakening reproduction of core regime elements, including radical policy reforms and deliberate replacement of incumbents (Turnheim and Geels, 2012, 2013). Kivimaa and Kern (2016) specified this as significant changes in regime rules, removing support for non-sustainable technologies, changing network patterns and introduction of new key regime actors. Accounting the above, to address the disruption-oriented change, we add a phase pertaining to the destabilisation process to the phases described in Section 2.3. This phase can happen simultaneously with, or before or after, niche specific processes of exploration, take-off and embedding.

Table 1 presents our analytical framework building on phases and levels of transition. Through this framework, we argue that the types, doings and origins of intermediaries can be conceptually differentiated on the basis of their level and phase of operation, as well as their way of emergence, and the agency and normative position they possess. With respect to levels, they can, for example, pursue activities within emerging niches or work on destabilising and restabilising regimes (or translating or forecasting landscape developments). They can also pursue mediating roles that further the transition between a niche and a regime, or between different regimes and regime-landscape relation. This differentiation is important from an analytical perspective and in considering what the agency and roles of intermediaries are in governing transitions.

To connect the range of perspectives on intermediaries offered in peer-reviewed academic articles, with phases of transitions, we operationalised the phases in as much detail as possible. For the operationalisation we drew from the literature describing phases of transitions (Rotmans et al., 2001; Safarzynska et al., 2012; van Lente et al., 2011) and the recent literature on the concept of destabilisation in the context of transitions (Turnheim and Geels, 2012, 2013; Kivimaa and Kern, 2016). The operationalisation took into account overlaps between phases, and acknowledged that most academic articles were not specific about the phase they address, which required interpretation and iteration by the authors. Table 1 outlines indicators for such operationalisation. 
Table 1. Analytical framework for the systemic review

\begin{tabular}{|c|c|c|c|c|}
\hline \multirow[t]{2}{*}{ Phase of transition } & \multicolumn{3}{|c|}{$\begin{array}{l}\text { Destabilisation (can precede or follow take-off I } \\
\text { acceleration) } \\
\text { Indicators: Significant changes in regime rules, dismantling } \\
\text { institutions, removal of support for non-sustainable } \\
\text { technology, changing network patterns, introduction of new } \\
\text { key regime actors, outlawing existing products and practices } \\
\text { (Sources: Turnheim \& Geels, 2012,2013; Kivimaa \& Kern, } \\
\text { 2016) }\end{array}$} & \multirow[b]{2}{*}{$\begin{array}{l}\text { Stabilisation } \\
\text { Indicators: } \\
\text { Speed of change decreases; } \\
\text { incremental innovation occurs; } \\
\text { new cycle of experimentation } \\
\text { and exploration of options } \\
\text { (Sources: Rotmans et al., } \\
\text { 2001; Safarzynska et al., 2012) }\end{array}$} \\
\hline & $\begin{array}{l}\text { Pre- } \\
\text { development / } \\
\text { exploration } \\
\text { Indicators: } \\
\text { experimentation } \\
\text { occurs, diverse } \\
\text { (technological) } \\
\text { options exist } \\
\text { (Source: } \\
\text { Safarzynska et } \\
\text { al., 2012) }\end{array}$ & $\begin{array}{l}\text { Take-off } \\
\text { Indicators: } \\
\text { explicit visioning } \\
\text { \& networking } \\
\text { occurs; transition } \\
\text { goals are set / } \\
\text { emerge; new } \\
\text { technologies / } \\
\text { services } \\
\text { accumulate \& } \\
\text { diffuse (Sources: } \\
\text { Safarzynska et } \\
\text { al., 2012; van } \\
\text { Lente et al., } \\
\text { 2011; Smith and } \\
\text { Raven, 2012) }\end{array}$ & $\begin{array}{l}\text { Acceleration and } \\
\text { Embedding } \\
\text { Indicators: } \\
\text { Collective learning; } \\
\text { institutional, cultural } \\
\text { \& economic } \\
\text { changes } \\
\text { accumulate; } \\
\text { deconstruction \& } \\
\text { alignment of } \\
\text { systems (Sources: } \\
\text { Rotmans et al., } \\
\text { 2001; Safarzynska } \\
\text { et al., 2012; van } \\
\text { Lente et al., 2011) }\end{array}$ & \\
\hline \multicolumn{5}{|l|}{$\begin{array}{l}\text { MLP level at which } \\
\text { intermediation takes } \\
\text { place (Sources: Rip } \\
\text { \& Kemp, 1998; Geels, } \\
\text { 2002, 2005): } \\
\text { Within regime, } \\
\text { between regime and } \\
\text { niche, } \\
\text { within niche }\end{array}$} \\
\hline \multicolumn{5}{|l|}{$\begin{array}{l}\text { Emergence and } \\
\text { evolution of } \\
\text { intermediary }\end{array}$} \\
\hline $\begin{array}{l}\text { Agency and } \\
\text { normative position of } \\
\text { intermediary }\end{array}$ & & & & \\
\hline
\end{tabular}

\section{Method and data}

To conceptually explore intermediaries in the context of societal transitions, we undertook a systematic review of academic literature, in a manner informed by Petticrew and Roberts (2006). We carried out a scientific literature repository search using key words, and expanded from the selected articles to the reference lists of those found. Our main focus was on those articles that explicitly used the terms 'intermediaries' or 'intermediation' in the context of sustainability transitions. In the literature, terms that partly (but not fully) contain similar ideas as the term 'intermediary' exist, including institutional entrepreneur, champion, change agent, system builder, knowledge broker, middle actor, hybrid actor, innovation broker. However, our interest was in particular on how the term intermediary was used in the sustainability transitions literature and, therefore, we did not include the other terms as search words.

First, we searched Scopus combining search terms 'transition*' and 'intermediar*' in the title-abstractkeywords fields. The following inclusion criteria were used: 1) the publication has to be a peer-reviewed 
piece of academic work in the field of social science and business studies, 2) thematically oriented to transition studies, undertaken at any time, and 3) appearing in Scopus at 11 July 2016. In addition, we applied the following exclusion criteria: 4) articles that do not address innovation or change in the context of socio-technical systems were excluded (i.e. the term 'transition' needed to be used in the sense of transformative change) and 5) articles in which the term "intermediary" was only used in passing (referring to 1-2 instances and not being part of the main focus) were excluded from our analysis. After more detailed inspection articles that did not principally focus on intermediation in the context of what can be regarded as a sustainability transition were also excluded from the review. This resulted in a set of 126 articles from which 26 articles were first included in the review. On the basis of more detailed reading 9 articles were omitted from qualitative analysis, leaving 17 articles to the initial pool.

Second, we complemented the search with another in Science Direct using terms "intermediar*" and "sustainability transitions" in the title-abstract-keywords fields, resulting in 47 hits from which we found 8 additional articles relevant for the review. While Scopus includes Science Direct journals, new articles are not updated to Scopus immediately after publication.

Third, the reference lists of the resulting 25 articles were searched for earlier papers, also taking into account terms with similar meaning. This backward snowballing resulted in 9 additional articles (and 9 earlier found articles) making the number of articles covered through qualitative in-depth review: 34 .

Finally, as the research in the area is developing rapidly, we tracked recent articles that cite the 34 articles in our set. We performed this forward snowballing by selecting for every article the 'cited by' option in Scopus. The resulting list of citing articles was then scanned: title, keywords and abstracts were read to assess inclusion. Recognising that there are terms such as 'middle actors' 'hybrid actors' or 'user assemblages' that may have the same extension as 'intermediaries' but would not come visible in our search, we included such papers, if they had been cited as evidence of transition intermediaries by the initial pool of papers. These procedures resulted in 11 new articles. We coded and analysed in total 62 articles that on the basis of abstracts that met the inclusion and exclusion criteria. A detailed content analysis revealed that 18 articles did not qualify to be part of the final review on the basis of the exclusion criteria.

All the selected 44 articles were read and coded by the first author. To check for consistency, randomly selected articles were independently read and coded by the second author, using the variables that are presented in the analytical framework (Table 1). No significant inconsistencies emerged. The list of codes is included in Appendix A.

\section{Results and discussion}

In this section we present and discuss the findings of the systematic literature review and, subsequently, fill in the gaps by suggesting transition intermediary processes in areas where the literature does not provide sufficient insight. First, we look at how intermediaries emerge in the context of transitions (Section 4.1). Second, we briefly discuss the agency and normative positioning of intermediaries (Section 4.2) and suggest that there is a range of intermediary types at play in transitions with differing characteristics, pertaining to the idea of the ecology of intermediaries we introduced in Section 2.1. This leads us to propose a typology of five transition intermediary types that contribute to different levels in transition (Section 4.3). Finally, we draw on the phases of transitions and end by demonstrating the range of processes that the different types of intermediaries take when a transition evolves (Section 4.4). 


\subsection{Emergence and evolution of transition intermediaries}

While many of the articles reviewed did not explicitly address the origin of intermediaries, 24 articles articulate the varying ways in which intermediary actions emerge as part of empirical descriptions of the cases.

Theoretically perhaps the clearest transition intermediary is one that is (1) specifically established or initiated to intermediate a transition process (e.g. Hodson and Marvin, 2009; 2010; Hamann and April, 2013; Hamilton et al. 2015), for example, to coordinate local actions with "sustainable" economic strategy of a city region (Hodson and Marvin, 2012) or to facilitate the implementation of "neighbourhood contracts" for urban renovation (Kampelmann et al. 2016). Hodson and Marvin (2010) argue that intermediaries need to be created as new forms of governance to boost transitions. This may occur in places where, for instance, innovation policy makers or cities play an active role in transforming governance (Klerkx and Leeuwis, 2009; Hodson et al., 2013).

Yet, more mentions as intermediaries in the systematic review get those already existing actors (organisations, individuals) who (2) assume intermediary roles and activities during their existence, while not initially set up to intermediate (e.g. Rohracher, 2009; Schreuer et al., 2010; Horne and Dalton, 2014; Judson et al., 2015; Mattes et al. 2015). These may be regime or niche intermediaries (see Section 4.2), for example, advancing energy efficient buildings (Fischer and Guy, 2009; Parag and Yanda, 2014), community energy (Martiskainen, 2016) or forest sector innovation (Berkvist and Soderholm, 2011). Indeed Judson et al. (2015) and Parag and Yanda (2014) argue for the importance of established actors in socio-technical systems to adopt roles to advance (low energy) transitions (also Fischer and Guy, 2009, for architects).

Equally common is that (3) transition intermediaries emerge (rather than are being set up) in the process of transition. They are neither existing organisations nor mandated to intermediate by some higher-level actor. They may appear in response to large-scale institutional change (e.g. Moss, 2009; Rohracher, 2009; Backhous, 2010; Moore et al., 2012) or to failures in markets and innovation systems to address sustainability concerns (e.g. van Lente et al., 2003, 2012; Klerkx and Leeuwis, 2009; Hamann and April; Hyysalo et al. 2013; Kivimaa, 2014; Nielsen, 2016). For instance, Moss argues that intermediaries may especially originate in response to market restructuring and new modes of regulation, and to fill institutional gaps (a finding supported by a case of fiscal reform in Canada, Moore et al., 2012). Hyysalo et al. (2013) show how peer advice on new renewable technologies accumulates in discussion forums in response to a lack of reliable information of the technology and product characteristics on the market (see also Heiskanen et al., 2014 and Hyysalo et al., 2017). Later, when a new regime stabilises, these emerging niche intermediaries may change role and become regime intermediaries (e.g. Berkvist and Soderholm, 2011).

Moss (2009) and Hodson et al. (2013) have made reference also to (4) transition intermediaries unaware of their intermediation. They can often be found at the interface of niches and the regime. Examples of such include social landlords (Judson et al., 2015), building professionals (Horne and Dalton, 2014) and architects translating building regulations into practice (Fischer and Guy, 2009) that may intermediate for a low energy buildings transition. Equally, user intermediaries, such as peers in internet discussion forums only gradually understand that they have come to play an important role (Hyysalo et al. 2013). From a transitions perspective these kinds of actors may be crucial in forming a critical mass for niche acceleration (see Section 4.4). For example, architects could play a significant, but so far not actualised, role in intermediating low energy building transitions (Fischer and Guy, 2009).

The above observations point also to the evolution of intermediaries. Changes in sociotechnical system configurations are likely to lead to the formation of new intermediaries, changing intermediary roles 
and, perhaps also, termination of others. Both van Lente et al. (2003) and Klerkx and Leeuwis (2009) make an argument for the emergence of more systemic (as opposed to firm-level and bilateral) intermediaries in the context of changing innovation systems. There are also sector-specific landscape dynamics that influence intermediary emergence. A type of origin specific to the liberalisation of the electricity markets is the creation of new intermediaries connecting unbundled parts of the system (e.g. Moss, 2009; Rohracher, 2009; Backhous 2010). Similarly references have been made for intermediation arising from deregulating the water market (Marvin and Medd, 2004; Moss, 2009).

The changing context may also create conflicts between intermediaries (e.g. Moore et al., 2012), taking focus away from the task at hand. As the proposals, solutions and uses that start as novel and different gradually tend to move towards normalcy and find their new institutional logics and stable actor configurations, a transition intermediary may transform to a more incremental regime player no longer able to act as an advocate or even a neutral party to niche innovation (e.g. Orstavik, 2014). Thus, over the course of a transition new intermediaries emerge and old ones cease to exist either intentionally, in the course of a 'battle' between actors, or accidentally. Also more long-term intermediaries may choose to have a limited role to play in a given transition (Klerkx and Leeuwis, 2009; Kivimaa, 2014).

\subsection{Agency and normative positions of transition intermediaries}

The systemic review demonstrated that, in the transition context, the ecology of intermediaries plays an important role in creating new markets for innovative solutions through pooling knowledge, finance and people (Klerkx and Leeuwis, 2009; Rohracher, 2009; Kivimaa, 2014), while simultaneously challenging existing market structures and voicing demands (Kivimaa, 2014), i.e. engaging in both niche support and regime destabilisation. The former roles resonate with those of innovation intermediaries (see Section 2.1). Further, the ecology of transition intermediaries condition the ways in which information is exchanged or translated and learning takes place, and advocate and deliberate interests (Geels and Deuten, 2006; Hodson and Marvin, 2009; Wihlborg and Soderholm, 2013; Seyfang et al., 2014). When doing the above, intermediaries influence the actual and perceived availability, economic viability, reliability and desirability of different systems of provision for consumers (Rohracher 2009; Moss 2009; Backhaus 2010; Barnes, 2016). The intermediating function (Fischer and Newig, 2016) can play out in a range of places as being situated in a certain part of a system.

The interface between niches and regimes is characterised by framing struggles and different storylines (Rosenbloom et al., 2016). Niche and regime actors interpret differently the need for transitions and the direction of change. In such struggles, intermediation may be relevant not only in connecting storylines of the niche and the regime (Hermans et al., 2016) but negotiating between different positions of actors within a niche or within a regime (between businesses, different government actors, etc.). At the interface of niches and the regime, intermediaries link niche actors with regime structures, aid in negotiating change by assisting in the building of alliances, and bring in supporters from within the regime (Diaz et al., 2013; Elzen et al., 2012; Hargreaves et al., 2013; Ingram, 2015; Smink et al., 2015; Hess, 2016). To be able to bridge between distinct actors, transition intermediaries have translation functions. For example, consumer preferences are translated towards technology developers, citizen demands for sustainability are translated towards the government to inform policies, and business knowledge needs are translated towards academia to inform research agendas. The roles of transition intermediaries go beyond the facilitation of networks by brokering relationships that aim at creating institutional spaces (e.g. transition arenas, urban living labs) to support niche innovation. Further, they articulate expectations and visions for a transformed society on the basis of such innovations (e.g. Kivimaa, 2014). This implies that they play a role in terms of the normative position of niches and regimes, in view of strategic goals in transition processes. 
While intermediaries are often labelled as 'neutral' or 'without specific agency' (Klerkx and Leeuwis, 2009; Backhaus, 2010; Kivimaa, 2014; Kampelmann et al. 2016; Parag and Yanda, 2014), there are questions about the degree of neutrality intermediaries actually can possess in connection to agency for change (cf. Kivimaa, 2014). The articles in the systematic review revealed that transition intermediaries are likely to possess some degree of 'bias' and 'agency' in relation to their normative position and strategic goals to support transitions. For example, intermediaries have been described as part of institutional regimes (Elzen et al., 2012; Kivimaa, 2014; Orstavik, 2014; Polzin et al., 2016) or they may be commercially or financially dependent in their intermediation activities (Fischer and Guy, 2009; Hodson and Marvin, 2012; Moore et al., 2012; Horne and Dalton, 2014). As indicated by Kivimaa (2014), neutrality or bias may be dependent on politics, finance and technological orientation. Possible biasness often links to the position of intermediaries as already existing players in a niche or a regime (e.g. Parag and Yanda, 2014 and Hamilton et al., 2015 conceptualisation of middle actors). In contrast, 'strategic intermediaries' are specifically established to intermediate between sets of different social interests (and technology), to produce an outcome that would not have been possible, or as effective, without their involvement (Hodson and Marvin, 2009). What is of relevance is the legitimacy that intermediaries possess in facilitating, brokering and configuring transitions. Some authors refer to 'collective good' (Geels and Deuten, 2006), 'societal benefit' (Hyysalo et al., 2013) or trustworthiness of knowledge (Wihlborg and Soderholm, 2013) rather than neutrality. The questions about trust and neutrality also link to how intermediaries originate (Section 4.1) and what role they play over the course of transitions (Section 4.4).

\subsection{Wrap-up: first conceptual interpretation and typology}

In Sections 4.1 and 4.2 we gained insights into how the articles effectively describe intermediaries with respect to their scale of action, emergence, agency and normative position. We combined these insights, created first a long list of intermediaries, and by identifying similar characteristics between descriptions, we were able to distil five broader types of transition intermediaries. The categories in the typology are not mutually exclusive. Yet, in practice many intermediaries are likely to be profiled more as one type than equally portraying the characteristics of several types:

(1) a systemic or strategic intermediary operating on all scales and taking a system perspective on change;

(2) a regime intermediary that is tied through, for example, institutional arrangements or interests to the established regime but has a specific mandate or goal to promote transition and, thus, interacts (often with a range of) niches;

(3) a niche intermediary typically working to experiment and advance niche activities as part of a particular niche but also trying to influence the regime level for that niche's benefit;

(4) a process intermediary that facilitates a change process or a project without explicit individual agency or agenda, but may work to advance priorities set externally by other actors; and

(5) a user intermediary translating new technologies to users and user preferences to developers, and qualifying the value of technology offers available.

The first three categories and the last category are intermediaries with a relatively strong agency to pursue sustainability transitions (even if systemic intermediaries may be regarded as neutral), whereas process intermediaries have merely a facilitating function and also differentiate from the others by being outsiders to both niches and the regime. Such process intermediaries are important in the overall 'ecology of intermediaries', because they can both carry out day-to-day work to concretely advance transitions and because they gain trust from other actors as neutral and unbiased due to the lack of 'personal' or 'institutional' agenda. We elaborate this typology in Table 2 drawing on part of our analytical framework (Table 1) and the literature review. 
Table 2: Transition intermediary types arising from systematic review

\begin{tabular}{|c|c|c|c|c|c|c|}
\hline \multirow[t]{2}{*}{ Category } & \multirow{2}{*}{$\begin{array}{l}\text { Scale of } \\
\text { action }\end{array}$} & \multirow[t]{2}{*}{ Origin } & \multirow[t]{2}{*}{ Agency } & \multicolumn{2}{|c|}{ Normative position } & \multirow[t]{2}{*}{ Sources } \\
\hline & & & & $\begin{array}{l}\text { Insider / } \\
\text { outsider }\end{array}$ & $\begin{array}{l}\text { Neutrality/ } \\
\text { interest }\end{array}$ & \\
\hline $\begin{array}{l}\text { Systemic (or } \\
\text { strategic) } \\
\text { intermediary }\end{array}$ & $\begin{array}{l}\text { Niche, } \\
\text { niche- } \\
\text { regime, } \\
\text { regime }\end{array}$ & $\begin{array}{l}\text { Typically } \\
\text { established } \\
\text { to } \\
\text { intermediate }\end{array}$ & $\begin{array}{l}\text { Pursues given } \\
\text { (sustainability) } \\
\text { goals on a } \\
\text { system level; } \\
\text { ambitiousness } \\
\text { towards } \\
\text { disruption to } \\
\text { existing } \\
\text { regime }\end{array}$ & $\begin{array}{l}\text { Insider or } \\
\text { outsider to } \\
\text { regime }\end{array}$ & $\begin{array}{l}\text { Typically } \\
\text { regarded or } \\
\text { established } \\
\text { seeking a } \\
\text { position of } \\
\text { neutral, } \\
\text { unbiased } \\
\text { facilitator } \\
\text { and broker }\end{array}$ & $\begin{array}{l}\text { Van Lente et al. } \\
\text { 2003; Medd \& } \\
\text { Marvin 2004, 2008; } \\
\text { Hodson \& Marvin } \\
\text { 2009; 2010; Klerkx \& } \\
\text { Leeuwis, 2009; } \\
\text { Backhaus 2010; } \\
\text { Kivimaa 2014; } \\
\text { Seyfang et al., 2014; } \\
\text { (Rohracher, 2009) }\end{array}$ \\
\hline $\begin{array}{l}\text { Regime } \\
\text { intermediary }\end{array}$ & $\begin{array}{l}\text { Niche- } \\
\text { regime, } \\
\text { regime }\end{array}$ & $\begin{array}{l}\text { Existing } \\
\text { actor } \\
\text { subsuming } \\
\text { intermediary } \\
\text { roles; } \\
\text { (sometimes } \\
\text { set up to } \\
\text { intermediate } \\
\text { regime } \\
\text { interests) }\end{array}$ & $\begin{array}{l}\text { Pursues given } \\
\text { (sustainability) } \\
\text { goals through } \\
\text { typically more } \\
\text { incremental } \\
\text { solutions or } \\
\text { political aims }\end{array}$ & $\begin{array}{l}\text { Insider to } \\
\text { the regime }\end{array}$ & $\begin{array}{l}\text { Regarded as } \\
\text { regime- } \\
\text { player but } \\
\text { pursuing or } \\
\text { empowered } \\
\text { for change }\end{array}$ & $\begin{array}{l}\text { Kivimaa 2014; } \\
\text { Hodson et al., 2013; } \\
\text { Berkvist \& } \\
\text { Soderholm 2011; } \\
\text { Parag \& Yanda 2014 } \\
\text { (middle actor); } \\
\text { Polzin et al. 2016 } \\
\text { (institutional } \\
\text { intermediary); } \\
\text { (Mattes et al. 2015) }\end{array}$ \\
\hline $\begin{array}{l}\text { Niche (or } \\
\text { grassroots) } \\
\text { intermediary }\end{array}$ & $\begin{array}{l}\text { Niche, } \\
\text { niche- } \\
\text { regime }\end{array}$ & $\begin{array}{l}\text { Often } \\
\text { emerging to } \\
\text { intermediate } \\
\text { when a } \\
\text { niche } \\
\text { develops }\end{array}$ & $\begin{array}{l}\text { Pursues given } \\
\text { (sustainability) } \\
\text { goals and } \\
\text { solutions from } \\
\text { a perspective } \\
\text { of a given } \\
\text { niche }\end{array}$ & $\begin{array}{l}\text { Insider to } \\
\text { the niche }\end{array}$ & $\begin{array}{l}\text { Regarded as } \\
\text { player } \\
\text { advancing a } \\
\text { particular } \\
\text { niche }\end{array}$ & $\begin{array}{l}\text { Geels \& Deuten } \\
\text { 2006; Seyfang et al., } \\
\text { 2014; Hargreaves et } \\
\text { al. 2013; Hamann \& } \\
\text { April, 2013; Fontes } \\
\text { et al. 2015; } \\
\text { Martiskainen } 2016\end{array}$ \\
\hline $\begin{array}{l}\text { Process (or } \\
\text { project) } \\
\text { intermediary }\end{array}$ & $\begin{array}{l}\text { Niche, } \\
\text { niche- } \\
\text { regime, } \\
\text { regime }\end{array}$ & $\begin{array}{l}\text { Set up } \\
\text { specifically } \\
\text { to } \\
\text { intermediate }\end{array}$ & $\begin{array}{l}\text { No particular } \\
\text { goals beyond } \\
\text { facilitating } \\
\text { interactions or } \\
\text { external/cont } \\
\text { ext-specific } \\
\text { priorities }\end{array}$ & $\begin{array}{l}\text { Outsider to } \\
\text { niche and } \\
\text { regime }\end{array}$ & $\begin{array}{l}\text { Regarded as } \\
\text { a neutral, } \\
\text { unbiased } \\
\text { 'networker' }\end{array}$ & $\begin{array}{l}\text { Elzen et al. 2012, } \\
\text { Parag \& Yanda, } \\
\text { 2014, Hodson \& } \\
\text { Marvin 2010; } \\
\text { Hodson et al., 2013, } \\
\text { Kampelmann et al. } \\
\text { 2016; (Audet and } \\
\text { Gyonnaud, 2013). }\end{array}$ \\
\hline $\begin{array}{l}\text { User } \\
\text { intermediary }\end{array}$ & $\begin{array}{l}\text { Niche, } \\
\text { niche- } \\
\text { regime, } \\
\text { regime }\end{array}$ & $\begin{array}{l}\text { Emerges } \\
\text { from amidst } \\
\text { users and } \\
\text { consumers }\end{array}$ & $\begin{array}{l}\text { Acts as } \\
\text { facilitator, } \\
\text { representative } \\
\text {, configurer or } \\
\text { broker of end- } \\
\text { use or end- } \\
\text { users. }\end{array}$ & $\begin{array}{l}\text { Insider to } \\
\text { niche or } \\
\text { regime }\end{array}$ & $\begin{array}{l}\text { Leans } \\
\text { towards } \\
\text { user } \\
\text { interests (in } \\
\text { some cases } \\
\text { even as } \\
\text { activists) }\end{array}$ & $\begin{array}{l}\text { Hyysalo et al., 2013; } \\
\text { Judson et al., 2015; } \\
\text { Barnes, 2016; } \\
\text { Kanger \& Schot, } \\
2016 .\end{array}$ \\
\hline
\end{tabular}

${ }^{a}$ Also regime intermediaries maintaining status quo are common but they are excluded from this categorisation focused on transition intermediaries.

\subsection{Intermediation in different transition phases}

Many of the articles we reviewed focus on examining a particular intermediary organisation or an actor (e.g. Fischer and Guy, 2009; Moore et al., 2012; Kivimaa, 2014; Grandclement et al., 2015; Kampelmann et al., 2016; Martiskainen, 2016). Others addressed more generally different types of 
intermediary roles or functions in specific contexts, such as the innovation system (e.g. Klerkx and Leeuwis, 2009; Polzin et al., 2016), or a transition domain, such as energy (Parag and Yanda, 2013; Hargreaves et al., 2013) or a city region (e.g. Hodson et al., 2013; Hamilton et al., 2015). Simultaneously, little insight is available on how intermediation changes throughout the transition. Intermediation in phases of transitions is previously explicitly only addressed by van Lente et al. (2012) who list possible roles for systemic intermediary organisations in different phases. We go beyond the focus of systemic intermediaries and discuss the contribution of those and other intermediary types (see Table 3) in phases of transitions. We review the ways in which the findings about intermediaries map onto idealised transition phases and provide our own suggestions to fill in the gaps, as the existing articles on transition intermediaries did not provide sufficient detail, particularly regarding the acceleration and embedding and the destabilisation phases.

\subsubsection{Pre-development and exploration}

The pre-development and exploration phase is likely to include both early niche intermediaries and systemic intermediaries creating institutional and societal space for alternative technologies, models and social constructs to emerge. For example, in the case of wave energy, "the early emergence of [niche] intermediary actors and formalization of arenas for debate favoured the conduction of fieldlevel aggregation activities" that guided the niche trajectory and articulated "a compelling vision of future benefits" (Fontes et al., 2016).

Closely related to the early niche intermediaries are 'grassroots' intermediaries that work bottom up to develop novel ideas and engage in a range of niche-specific experiments. Grassroots intermediation can occur before an explicit niche has necessarily formed, or exists at most at local or city scale (national and global links yet to form). This is shown in the case of community energy initiatives in the UK (Hargreaves et al., 2013; Martiskainen, 2016), although community energy intermediaries may also play a role in the later stage of technology diffusion (Barnes, 2016; De Vries et al., 2016). In the predevelopment and exploration phase, grassroots intermediaries coordinate local projects that exist in spaces where 'the rules are different' from (and at times oppositional to) the mainstream (Hargreaves et al., 2013), voicing expectations and engaging in learning activities (Martiskainen, 2016).

Although grassroots initiatives clearly perform intermediary activities, they sometimes do not have the ambition to be central actors in transitions. The same applies to ambitions regarding upscaling: Hargreaves et al. (2013) point out that not all grassroots innovations wish to grow and diffuse, i.e. they may exist without major transition visions. In addition to grassroots intermediation, 'piecemeal' (process) intermediation in local contexts may take place addressing the coordination of local projects to meet local interests (Hodson et al., 2013). The same goes for nascent user intermediaries involved in innovating in their own equipment and sharing their insights among peers, thus, forming initial knowledge sharing networks (Hyysalo et al., 2013). To address pressing social and environmental challenges, we need to consider how to get such intermediaries to broaden attention into 'growing' or 'diffusing', Or, if also other types of intermediaries are needed, when these upscaling functions go against the grain of the typical grassroots activities.

Systemic or regime intermediaries are also important in this phase. They can help to find new sources of funding for basic and applied research and development stages, potentially characterised by high technological and market uncertainty and a general underinvestment in R\&D (Polzin et al., 2016). Hargreaves et al. (2013) argue that "intermediation may be more about opening up space in different contexts (whether local, policy, market, social etc.) for new and diverse kinds of activity, rather than about developing a single successful approach or a strategic vision for its growth and diffusion". This is supported by van Lente et al. (2003) in their depiction of systemic intermediaries operating in this 
phase in a way that - rather than having specific technology in mind - enhances the articulation of societal needs and demands for transition and make the variety of technical options more visible (also van Lente et al. 2012). Klerkx and Leeuwis (2009) underline this by regarding a role for systemic intermediaries as catalysts of innovation, for example in setting up niche experiments (see also Kivimaa, 2014). In effect, grassroots, user and systemic intermediaries can promote and diffuse a range of new niche ideas (e.g. Fischer and Newig, 2016; Nielsen, 2016).

\subsubsection{Take-off}

The take-off phase connects to the idea of strategic management of sustainability niches, and the processes of visioning, networking and learning (e.g. Hargreaves et al., 2013; Kivimaa, 2014). Most articles on transition intermediaries seem to address this phase. In the beginning of the take-off phase, connections between local and global developments are important (Geels and Deuten, 2006; Hargreaves et al., 2013; Seyfang et al., 2013; Fontes et al., 2016) to move beyond individual experiments towards a 'successful' niche. To improve the knowledge flows between local experiments and a global niche, intermediation is characterised by increased production and circulation of knowledge that is not intended for use in specific local practices, but rather for the field as a whole (Geels and Deuten, 2006).

In this phase, new institutional actors such as professional societies, industry associations and standardisation organisations act as niche intermediaries. These actors perceive themselves as part of an emerging community with collective interests to both aggregate knowledge and guide local developments (Geels and Deuten, 2006). They make connections between particular and often isolated local innovation projects and with the wider world (cf. Howells, 2006). By doing 'relational work' (Moss, 2009), intermediaries "are able to identify common issues and problems encountered across multiple local projects, and can therefore support niche development and diffusion by sharing this knowledge more widely, helping subsequent projects to benefit from accumulated experience" (Hargreaves et al., 2013). In this, campaigning and advocacy activities play a role (White and Stirling, 2013). Intermediaries aggregate not only new knowledge but also resources helping to nurture the niche (which may suffer from lack of resources and institutional support) through replication of projects, and influence regimes to adopt niche ideas and practices (Seyfang et al., 2014).

In addition to connecting local with the global scale, the take-off phase can benefit from systemic intermediaries. They aim to create new markets (without being technology-specific) and provide guidance and transparency to consumers regarding a variety of options, simultaneously articulating demands for producers (Klerkx and Leeuwis, 2009; Rohracher, 2009; Hyysalo et al. 2013; Kivimaa, 2014). Intermediaries developing a shared institutional infrastructure (Geels and Deuten, 2006; Hargrieves et al., 2013) and, thus, contributing to both knowledge building and market formation are crucial.

The types of intermediaries differ in whether they wish to engage in radical political activism or more reformist and incremental practical action (Hargreaves et al., 2013). Kivimaa (2014) notes that regime intermediaries are more likely to take on the latter role than intermediaries operating at the niche level. Existing actors can take on roles of regime intermediaries and form networks with newly set-up transition intermediaries (e.g. Mattes et al., 2015), thereby building a new ecology of intermediaries. Alternatively, regime intermediaries can speed up niche innovation processes by "supporting the design of a policy environment that is conducive to the innovation process" (Poltzin et al., 2016). While van Lente et al. $(2003,2012)$ are not very elaborate of the role of systemic intermediaries during take-off, they see potential roles for such actors to be akin to evaluators identifying promising niches and networking for a critical mass of stakeholders to support take-off. 
Finally, user intermediaries are important in instructing technology to users, in qualifying the characteristics and suitability of new technological options for different contexts, and in configuring together technical and social elements of innovation (Hyysalo et al., 2013; Judson et al., 2015; de Vries et al. 2016). At the same time, they articulate demands that their user constituency has about (future) requirements regarding emerging (sustainable) technologies, and act as a back-channel to claims and actions by vendors, assemblers and maintenance technicians (Hyysalo et al. 2013).

\subsubsection{Acceleration and embedding}

Following Smith and Raven (2012) and as described in Section 2, embedding pertains to empowerment of niches to gradually form part of the regime. Empowerment occurs in two ways: 'stretch-andtransform' and 'fit-and-conform' (Section 2.2). In the literature, much attention is being paid to niche development (and to some extent also destabilisation), rather than niche-regime interaction and the role intermediaries play in such interaction. Therefore, our conceptualisation here is tentative and we make our own propositions as to the core functions of intermediaries.

Even as the reviewed articles provide limited evidence, we assume that many niche and systemic intermediaries that were present in the take-off phase still need to continue operating, possibly strengthening some activities (e.g. for creating new institutions and markets) and weakening others (e.g. aggregation and distribution of project knowledge). From the reviewed articles we learnt that new regime building is carried out by user intermediaries increasing the size and stability of the accelerating niche (Kanger and Schot, 2016) and by systemic intermediaries articulating, negotiating and aligning the various perspectives to be more compatible with each other, advancing standardisation and preventing strategic games (van Lente et al., 2003, 2012; Rohracher, 2009). Niche intermediaries can simultaneously try to lobby for recognition and resources in political strategies for the accelerating niche (White and Stirling, 2013).

In stretch-and-transform embedding, regime building and negotiation are likely to be prevalent activities, while in fit-and-conform, intermediaries may aim for raising public awareness rather than for letting users actively influence the transition (Mattes et al., 2015). The role of intermediaries has been argued to become less visible as the technology matures; a relevant function during commercialisation and diffusion being the mitigation of uncertainty and risk between firms or research institutes and potential financiers (Polzin et al. 2016). However, a diffusion of maturing technology may also create new intermediaries to emerge both at supply side and user side, as shown in the case of heat pumps (Hyysalo et al., 2013; Heiskanen et al. 2014).

Moss (2009) has generally outlined that further research is needed exploring intermediation between new technologies and sustainable forms of production and consumption, and in embedding technologies in particular social contexts of application. Our review confirms the need for more research about intermediation in this phase, particularly as many key technologies in sustainability transition have recently moved towards or even into the embedding phase.

\subsubsection{Destabilisation (and stabilisation)}

Destabilisation as a phase can precede, or run in parallel to phases of exploration, take-off, and acceleration and embedding - being particularly closely related to the latter. It departs from the perspective of an extant regime that is shifting either stimulated by niche developments or influenced by landscape changes - change can also originate from within the regime (see work on transition pathways by Schot and Geels, 2007). The timing of destabilisation vis-à-vis the other phases partly influences the kind of intermediaries that emerge and take action. In general our review finds either intermediaries originating as a result of destabilisation (Backhous, 2010; Fischer and Guy, 2009; Moss, 
2009; Rohracher, 2009) or somehow influencing destabilisation (Klerkx and Leeuwis, 2009; Orstavik, 2014; Kivimaa, 2014).

Kivimaa (2014) stated that "[i]ntermediaries may attempt to destabilise dominant regimes... by aiming to decrease public legitimacy for and endogenous commitment to an existing regime, or unintentionally disrupt existing structures. "Systemic (e.g. van Lente et al., 2003; Klerkx and Leeuwis, 2009; Kivimaa, 2014) and strategic intermediaries (e.g. Hodson and Marvin, 2009; Rohracher, 2009) can be seen as important actors in this phase. Systemic intermediaries, operating on a system level and aiming for systemic change, may aim to disrupt existing institutional frameworks or markets (Kivimaa, 2014; see also Nielsen, 2016) or destruct existing networks and set up new networks that disturb existing structures (Klerkx and Leeuwis, 2009; Hodson and Marvin, 2009). In that sense, they can simultaneously facilitate a take-off of a broader niche and try to destabilise the regime from within. They are facing other kinds of intermediaries as a counterforce that may "thwart rather than promote potentially useful but disruptive innovations" (Orstavik, 2014).

Destabilising regimes, exemplified through transforming infrastructure systems, generate demand for new forms of coordination and intermediation not previously required or recognised (Backhous, 2010; Moss, 2009; Rohracher, 2009). Intermediaries can seize novel business opportunities in a newly stabilised regime, simultaneously shaping or transforming the regime (Rohracher, 2009) to the pursuit of their own and common objectives. If destabilising policy measures are carried out (Kivimaa and Kern, 2016), intermediaries can translate such new forms of regulation into practice (Fischer and Guy, 2009; Moss, 2009) or make sense of a complex and changing policy environment to niche innovators. Importantly, both Moss (2009) and Rohracher (2009) argue for the emergence of intermediary organisations that liaise between producers/suppliers and consumers in the changing market context. While Rohracher is focused on the role of non-governmental organisations, Moss describes a range of intermediaries (advisory groups, information campaigns, educational programmes) that can take on this role.

\subsection{Wrap-up: dynamics of intermediaries in transitions}

Table 3 summarises the functions of different types of transition intermediaries over the transition phases. Many functions are based on our literature review as interpreted by the authors. Some other functions are deduced propositions, in the absence of literature. These are marked with asterisk (*). Systemic intermediaries have important roles throughout the transition, while other intermediaries, particularly process and user intermediaries, may have more temporal and limited roles and experience shifts in the role they play in transition. Niche intermediaries may seize to exist after take-off or acceleration and embedding, or transform their role to a regime intermediary (even resisting change) in the new stabilised regime. Systemic intermediaries are likely to look out for new issues requiring their attention and pulling off from activity related to a particular sociotechnical system or subsystem after some time has elapsed (cf. Kivimaa, 2014) or at latest in the stabilisation phase. 
Table 3 Summary of classification of innovation intermediaries' activities, differentiated by level, origin and phase.

\begin{tabular}{|c|c|c|c|c|}
\hline \multirow{3}{*}{ Phase of transition } & \multicolumn{3}{|c|}{$\begin{array}{l}\text { Destabilisation (can precede or follow take-off / } \\
\text { acceleration) }\end{array}$} & \\
\hline & \multicolumn{3}{|c|}{$\begin{array}{l}\text { Systemic intermediaries decreasing public legitimacy for and } \\
\text { endogenous commitment to an existing regime; destructing } \\
\text { existing networks, markets and institutions; translating new } \\
\text { forms of regulation to practice. }\end{array}$} & \multirow[b]{2}{*}{ Stabilisation } \\
\hline & $\begin{array}{l}\text { Pre- } \\
\text { development / } \\
\text { exploration }\end{array}$ & Take-off & $\begin{array}{l}\text { Acceleration \& } \\
\text { embedding }\end{array}$ & \\
\hline $\begin{array}{l}\text { Niche level } \\
\text { intermediation }\end{array}$ & $\begin{array}{l}\text { Niche, user, } \\
\text { process \& } \\
\text { systemic } \\
\text { intermediaries } \\
\text { promoting } \\
\text { experimentation } \\
\text { \& coordinating } \\
\text { projects. }\end{array}$ & $\begin{array}{l}\text { Niche intermediaries } \\
\text { aggregating } \\
\text { knowledge, guiding } \\
\text { local experiments, } \\
\text { replicating projects } \\
\text { and pooling } \\
\text { resources. } \\
\text { User intermediaries } \\
\text { configuring systems } \\
\text { and uses, qualifying } \\
\text { claims by producers } \\
\text { and resellers; } \\
\text { articulating demand } \\
\text { for niche producers. }\end{array}$ & $\begin{array}{l}\text { Process } \\
\text { intermediaries } \\
\text { facilitating } \\
\text { embedding of } \\
\text { niches (that they are } \\
\text { outsiders to) to } \\
\text { particular contexts } \\
\text { of application }\end{array}$ & $\begin{array}{l}\text { Niche, user, process and } \\
\text { systemic intermediaries } \\
\text { promoting experimentation } \\
\text { \& coordinating projects. }\end{array}$ \\
\hline $\begin{array}{l}\text { Niche-regime } \\
\text { intermediation }\end{array}$ & $\begin{array}{l}\text { Process } \\
\text { intermediaries } \\
\text { connecting } \\
\text { context-specific } \\
\text { regime priorities } \\
\text { and local } \\
\text { projects. } \\
\text { Regime \& } \\
\text { systemic } \\
\text { intermediaries } \\
\text { finding and } \\
\text { directing } \\
\text { funding for } \\
\text { niche R\&D } \\
\text { activities. }\end{array}$ & $\begin{array}{l}\text { Regime } \\
\text { intermediaries } \\
\text { supporting } \\
\text { incremental niche } \\
\text { build up through } \\
\text { practical action \& } \\
\text { forming networks } \\
\text { with other transition } \\
\text { intermediaries. } \\
\text { Niche intermediaries } \\
\text { developing shared } \\
\text { institutional } \\
\text { infrastructure (e.g. } \\
\text { standard bodies). } \\
\text { Systemic (\& regime) } \\
\text { intermediaries } \\
\text { engaging in market } \\
\text { creation and } \\
\text { identification / } \\
\text { evaluation of } \\
\text { promising niches. }\end{array}$ & $\begin{array}{l}\text { Niche intermediaries } \\
\text { supporting niche } \\
\text { embedding (aiming } \\
\text { to increase size and } \\
\text { stability) or seizing } \\
\text { to exist / changing } \\
\text { roles* } \\
\text { Systemic } \\
\text { intermediaries } \\
\text { aligning different } \\
\text { perspectives and } \\
\text { preventing strategic } \\
\text { games } \\
\text { User intermediaries } \\
\text { facilitating } \\
\text { technology adoption } \\
\text { and reconfiguration } \\
\text { by users }\end{array}$ & $\begin{array}{l}\text { Process intermediaries } \\
\text { connecting context-specific } \\
\text { local priorities and local } \\
\text { projects } \\
\text { Regime \& systemic } \\
\text { intermediaries finding and } \\
\text { directing funding for niche } \\
\text { R\&D activities. }\end{array}$ \\
\hline $\begin{array}{l}\text { Regime level } \\
\text { intermediation }\end{array}$ & $\begin{array}{l}\text { Systemic } \\
\text { intermediaries } \\
\text { articulating } \\
\text { societal needs } \\
\text { for change and }\end{array}$ & $\begin{array}{l}\text { Systemic } \\
\text { intermediaries } \\
\text { articulating societal } \\
\text { needs for change } \\
\text { and creating political }\end{array}$ & $\begin{array}{l}\text { Systemic } \\
\text { intermediaries } \\
\text { maintaining/ } \\
\text { strengthening }\end{array}$ & $\begin{array}{l}\text { New regime intermediaries } \\
\text { emerging to fill institutional } \\
\text { gaps, in response to new } \\
\text { governance modes or to } \\
\text { market restructuring }\end{array}$ \\
\hline
\end{tabular}




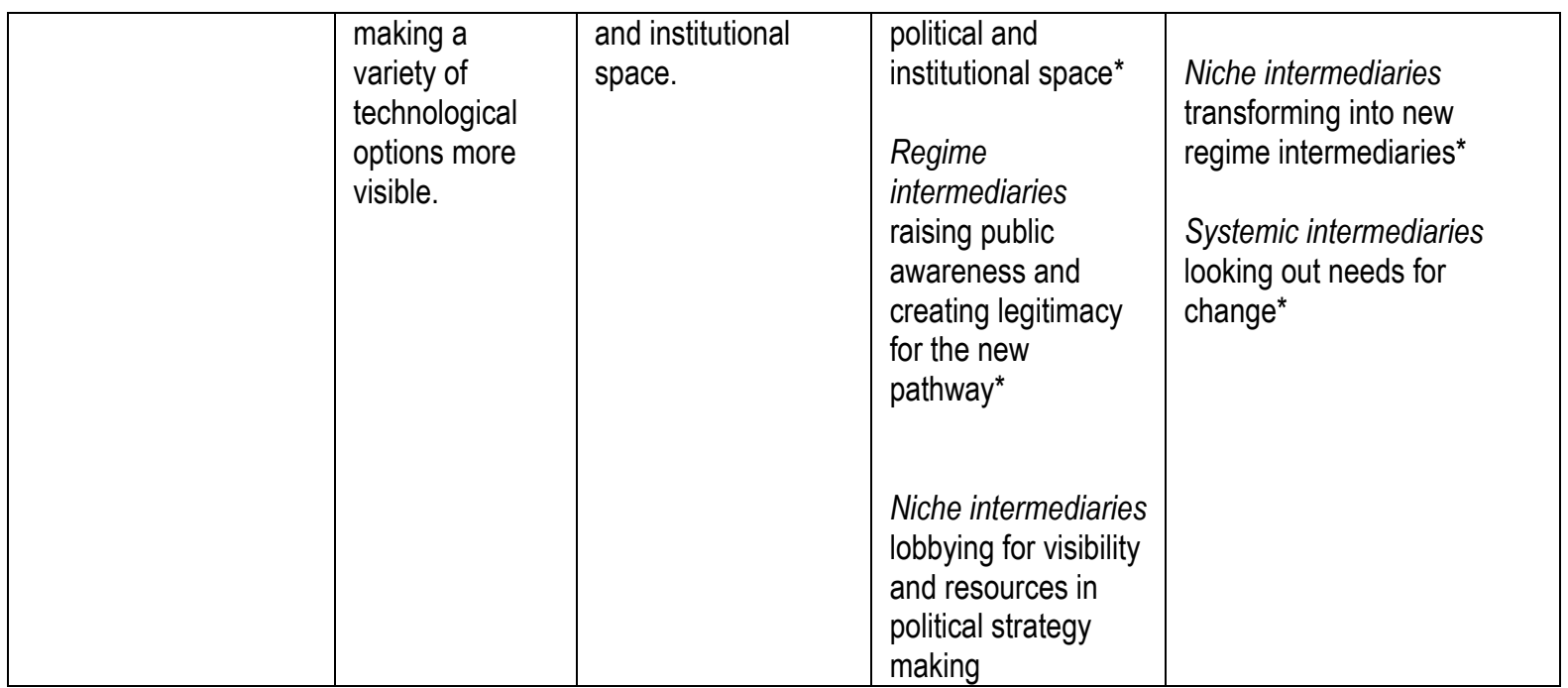

\section{Conclusions}

\subsection{Theoretical implications}

The aim of this paper was to bring more clarity to the topic of intermediaries in transitions, providing a typology that is sensitive to different phases of transitions and levels through which transitions takes place, the processes intermediaries are engaged in, and how transition intermediaries originate in the first place. When collecting and analysing the set of articles for the systematic review, we noted that the literature on intermediaries in transitions is incoherent and fragmented as well as rapidly expanding, and we hope our paper provides steps towards better coherence.

We found several conceptualisations of innovation intermediaries in the sustainability transitions literature. In terms of origin, not many examples in empirical literature exist of setting up and giving a mandate for specific transition intermediaries to operate. Research that shows or assumes intermediary roles to emerge gradually in response to socio-institutional pressures and technological developments is more prevalent. These can either be new intermediary organisations or platforms, or already established actors taking up intermediary functions - in the latter case actors not always being aware that they are intermediaries. By looking at common denominators and differences in terms of level of action, emergence and evolution, and agency and normative position, we can distinguish five different types of transition intermediaries, namely, systemic, regime, niche, process, and user intermediaries. To existing literature we, thus, first, add the notions of a regime intermediary and a process intermediary and, second, clarify the different uses of the intermediary term in transition studies through our typology. Regime intermediaries geared towards transitions operate within their possibilities as regime players to promote the change agenda and partly work against those intermediaries, such as many incumbent industry bodies that keep to maintain status quo in in the regime (i.e. non-transition intermediaries). Process intermediaries focus mostly on making day-to-day work towards a transition more effective gaining trust from other actors as neutral and unbiased as a result of lacking 'personal' or 'institutional' agenda. They do not exercise clear normative interests in which direction the transition process should be heading; rather as outsiders to niches and the regime, they support other actors to articulate this direction, help them negotiate within niches or with regime actors. They have the position and capability to be mediators, and also fulfil coordination roles.

Transition-oriented activities have an inherently dynamic dimension. By this we mean that the emergence of sustainable niche innovations is associated with creating and maintaining development pathways in which actors (intermediaries and others) have different roles that also change over time. 
While attention has been given to different roles of transition intermediaries in general, attention has not been paid to intermediation in different transition phases. Thus, drawing on selected articles we elaborated on intermediation in pre-development, take-off, acceleration and embedding, destabilisation and stabilisation phases, showing that important intermediation takes place in all the phases as well as on the scales of niche and regime and their intersection. Particularly systemic and niche intermediaries appear both to be key actors in transitions, while support from regime, process and user intermediaries is also relevant. Changes in intermediary actors and functions are partially related to different phases of transitions but also to battles between different intermediaries. Change in intermediation happens, first, within a specific intermediary (that initially emerges or is set up and later may seize to exist, or subsume and let go all or some of its intermediary functions). Second, the ecology of intermediaries that contributes to the transition over time on different scales (within niches, at the niche-regime interface, and within regimes) also changes. The longevity of a specific intermediary can exceed or be much more limited than the duration of a transition.

\subsection{Policy implications}

From the policy perspective our concentrated look on intermediaries offers both an encouraging and challenging message. The encouraging part is that many necessary intermediaries appear to emerge in the course of the transition, when different actors respond to knowledge, coordination and service gaps regarding the alternative solutions in the market, or pressing societal concerns. An ecology of intermediaries may, therefore, come into being and evolve adequately, partly on its own accord. If it does so sufficiently, it can importantly contribute to the polycentric governance in transformative change. However, this emerging ecology of intermediaries may also lack sufficient direction, willingness or speed to grow to support the later phases of transitions, during which old structures get destabilised and niche innovations get embedded. Or even when remotely successful, it may not cover all necessary intermediating functions or roles.

The challenging part, thus, follows and calls for policy capacity to (1) monitor the continuously evolving transition processes and associated intermediary action. In many cases, policymakers may need to (2) set up new or support existing intermediaries, and (3) make sure that policies do not curtail excessively the operational space of already existing transition intermediaries. Examples show that policy changes can eradicate forms of intermediation directly and as collateral damage of laws passed for other purposes (Torrance \& von Hippel, 2016). We further suggests that innovation policy would benefit from having a versatile toolkit of action for supporting, transforming, setting and disbanding temporary and more permanent transition intermediaries. Whilst such monitoring capacity and toolkits are something that some systemic intermediaries might already provide through their remit (an example being the National Innovation Fund SITRA in Finland (Kivimaa, 2014)), such systemic competency regarding intermediary activities is by no means easy to attain or retain, or to communicate effectively into different policy making arenas.

While we find that there are intermediaries which fit our tentative definition of a 'transition intermediary', our evidence from the review papers is inconclusive regarding how, for example, governments can purposefully employ intermediaries to direct transitions. Yet, there is evidence that a well-functioning ecology of intermediaries can speed up diffusion, further improvement and institutional reform needed for niche formation and expansion. Supporting and setting up of niche intermediaries can, therefore, speed up some developments over others. It is, thus, a policy option for furthering transitions but also a dynamic to which transition policy needs to be vigilant over. Supporting and setting up of systemic intermediaries that have a broader scope of creating space for a variety of 
niches and simultaneously destabilise existing structures, is an alternative policy option that takes a less selective approach on transformative change.

\subsection{Future research avenues}

Our findings point out a need for more empirical research on the kinds of intermediary activities that are relevant for different phases of transitions, and how the dynamics of intermediation changes during the transition. Future research avenues could focus on (1) the processes of acquiring and losing of intermediary position, (2) what kind of intermediation takes place and is required in the acceleration and embedding and the destabilisation phases of transitions, and (3) what is the importance of heterogeneous mixes of intermediaries in transformative innovation policy and governance.

\section{Acknowledgements}

This work has been equally funded by the UK EPSRC through the Centre for Innovation and Energy Demand (grant number EP/K011790/1) and by the Academy of Finland through the consortium project "Intermediaries in the energy transition: The invisible work of creating markets for sustainable energy solutions (TRIPOD)" (decision numbers 288796 and 290288). We thank the editor and two anonymous reviewers of the SPRU working paper series for their excellent comments. An earlier version of this paper was presented at the SPRU 50 Anniversary Conference in Brighton, 7-9 September 2016, Brighton.

\section{References}

Audet R, Gyonnaud M-F 2013. Transition in practice and action in research. A French case study in piloting eco-innovations. Innovation: The European Journal of Social Science Research 26(4): 398415 .

Backhaus J. 2010. Intermediaries as Innovating Actors in the Transition to a Sustainable Energy System. Central European Journal of Public Policy 4(1): 86-109.

Barnes J. 2016. The local embedding of technologies through community-led initiatives: the case of sustainable energy. Doctoral thesis (PhD), University of Sussex.

Berkvist, A-K, Soderholm, K. 2011. Green Innovation Systems in Swedish Industry, 1960-1989. Business History Review 85: 677-698

Bessant J, Rush H. 1995. Building bridges for innovation: the role of consultants in technology transfer. Research Policy, 24: 97-114.

Boon W, Moors E, Kuhlmann S, Smits R. 2011. Demand articulation in emerging technologies: intermediary user organisations as co-producers? Research Policy 40: 242-252.

Dedehayir, O., Mäkinen, S.J., Roland Ortt, J., 2016. Roles during innovation ecosystem genesis: A literature review. Technological Forecasting and Social Change, in press.

Den Hertog P. 2000. Knowledge-intensive business services as coproducers of innovation. International Journal of Innovation Management 4: 491-528.

de Vries G.W., Boon W.P.C., Peine A. 2016. User-led innovation in civic energy communities. Environmental Innovation and Societal Transitions, 19, 51-65.

Diaz M, Darnhofer I, Darrot C, Beuret J.-E. 2013. Green tides in Brittany: What can we learn about niche-regime interactions? Environmental Innovation and Societal Transitions 8, 62-75 
Elzen B, van Mierlo B, Leeuwis C. 2012. Anchoring of innovations: Assessing Dutch efforts to harvest energy from glasshouses. Environmental Innovation and Societal Transitions 5: 1-18.

Farla J, Markard J, Raven R, Coenen L. 2012. Sustainability transitions in the making: A closer look at actors, strategies and resources. Technological Forecasting and Social Change 79, 991-998.

Fischer J, Guy S. 2009. Re-interpreting Regulations: Architects as Intermediaries for Low-carbon Buildings. Urban Studies 46(12): 2577-2594.

Fischer L-B, Newig J. 2016. Importance of Actors and Agency in Sustainability Transitions: A Systematic Exploration of the Literature. Sustainability.

Fontes M, Sousa C, Ferreira J. 2016. The spatial dynamics of niche trajectory: The case of wave energy. Environmental Innovation and Societal Transitions 19: 66-84.

Franks J. 2010. Boundary organizations for sustainable land management: The example of Dutch Environmental Co-operatives. Ecological Economics 70: 283-295.

Fuenfschilling L, Truffer B. 2013. The structuration of socio-technical regimes-Conceptual foundations from institutional theory. Research Policy 43: 772-791.

Geels F. 2002. Technological transitions as evolutionary reconfiguration processes: a multi-level perspective and a case-study. Research Policy, 31, 1257-1274

Geels F. 2005. Processes and patterns in transitions and system innovations: Refining the coevolutionary multi-level perspective. Technological Forecasting \& Social Change 72: 681-696.

Geels F, Deuten J. 2006. Local and global dynamics in technological development: a socio-cognitive perspective on knowledge flows and lessons from reinforced concrete. Science and Public Policy 33: $265-275$.

Geels F, Kern F, Fuchs G, et al. 2016. The enactment of socio-technical transition pathways: A reformulated typology and a comparative multi-level analysis of the German and UK low-carbon electricity transitions (1990-2014). Research Policy 45: 896-913.

Geels F.W., Schot J. 2007. Typology of sociotechnical transition pathways. Research Policy 36: 399417.

Grandclement C, Karvonen A, Guy S. 2015. Negotiating comfort in low energy housing: The politics of intermediation. Energy Policy, 84, 213-222.

Guy et al. 2010. Shaping Urban Infrastructures: Intermediaries and the Governance of Socio-Technical Networks. Taylor and Francis.

Hamann R, April K. 2013. On the role and capabilities of collaborative intermediary organisations in urban sustainability transitions. Journal of Cleaner Production 50: 12-21.

Hamilton J, Mayne R, Parag Y, Bergman N. 2015. Scaling up local carbon action: the role of partnerships, networks and policy. Carbon Management.

Hargreaves T, Hielscher S, et al. 2013. Grassroots innovations in community energy: the role of intermediaries in niche development. Global Environmental Change 23: 868-880.

Heiskanen E, Hyysalo S, Jalas M, Juntunen J, Lovio R. 2014. User involvement and radical innovation: The case of heat pumps in Finland. In Juninger S, Christensen P. (Eds.), Highways and Byways of Radical Innovation: The perspective of design. Kolding Design School: Kolding, pp. 171-192.

Hess, D. 2016. The politics of niche-regime conflicts: Distributed solar energy in the United States. Environmental Innovation and Societal Transitions 19: 42-50.

Hermans F, Roep D, Klerkx L. 2016. Scale dynamics of grassroots innovations through parallel pathways of transformative change. Ecological Economics 130, 285-295. 
Hodson M, Marvin S. 2009. Cities mediating technological transitions: Understanding visions, intermediation and consequences. Technology Analysis and Strategic Management 21(4): 515-534.

Hodson, M., Marvin, S., 2010. Can cities shape socio-technical transitions and how would we know if they were? Research Policy 39: 477-485.

Hodson M, Marvin S, Bulkeley H. 2013. The Intermediary Organisation of Low Carbon Cities: A Comparative Analysis of Transitions in Greater London and Greater Manchester. Urban Studies 50(7): 1403-1422.

Howells J. 2006. Intermediation and the role of intermediaries in innovation. Research Policy 35: 715728.

Hoogma R, Kemp R, Schot J, Truffer B. 2002. Experimenting for SustainableTransport: The approach of Strategic Niche Management. London: Spon Press.

Horne R, Dalton T. 2014. Transition to low carbon? An analysis of socio-technical change in housing renovation. Urban Studies, 51, 3445-3458.

Hyysalo S. 2010. Health Technology Development and Use: From Practice Bound Imagination to Evolving Impacts. London: Routledge.

Hyysalo S, Juntunen J, Freeman S. 2013. Internet forums and the rise of the inventive energy user. Science and Technology Studies 26(1): 25-51.

Hyysalo S, Usenyuk S. 2015. User dominated technology era - Dynamics of dispersed peer innovation. Research policy. 44 (3), 560-576.

Hyysalo, S. Johnson, J Juntunen, J. 2017. The Diffusion of Consumer Innovation in Sustainable Energy Technologies. Journal of Cleaner Production.

Ingram J. 2015. Framing niche-regime linkage as adaptation: An analysis of learning and innovation networks for sustainable agriculture across Europe. Journal of Rural Studies 40: 59-75.

Johnson W.H.A. 2008. Roles, resources and benefits of intermediate organizations supporting triple helix collaborative R\&D: The case of Precarn. Technovation 28: 495-505.

Judson E, Bell S, Bulkeley H, Powells G, Lyon S. 2015. The co-construction of energy provision and everyday practice: integrating heat pumps in social housing. Science and Technology Studies 28: 26-53.

Kampelmann S, Van Hollebeke S, Vandergert P. 2016. Stuck in the middle with you: The role of bridging organisations in urban regeneration. Ecological Economics, 129, 82-93.

Kanger L, Schot J (2016) User-made immobilities: a transitions perspective. Mobilities, 11 (4). 598 613.

Katzy B, Turgut E, Holzmann T, Sailer K, 2013. Innovation intermediaries: A process view on open innovation coordination. Technology Analysis and Strategic Management 25: 295-309.

Kemp R, Schot J, Hoogma R. 1998. Regime shifts to sustainability through processes of niche formation: the approach of strategic niche management. Technology Analysis \& Strategic Management 10: 175-195.

Kivimaa, P. 2014. Government-affiliated intermediary organisations as actors in system-level transitions. Research Policy, 43(8): 1370-1380.

Kivimaa P, Kern F. 2016. Creative destruction or mere niche support? Innovation policy mixes for sustainability transitions. Research Policy, 45(1): 205-217. 
Kivimaa P, Boon W, Antikainen R (2017a). Commercialising university inventions for sustainability a case study of (non-)intermediating 'cleantech' at Aalto University. Science and Public Policy, in press.

Kivimaa P, Hildén M, Huitema D, Jordan A, Newig J (2017b). Experiments in climate governance -a systematic review of research on energy and built environment transitions. Journal of Cleaner Production, in press.

Klerkx, L., Aarts, N., 2013. The interaction of multiple champions in orchestrating innovation networks: Conflicts and complementarities. Technovation 33, 193-210.

Klerkx L, Leeuwis C, 2009. The emergence and embedding of innovation brokers at different innovation system levels: Insights from the Dutch agricultural sector. Technological Forecasting and Social Change 76: 849-860.

Lichtenthaler U. 2013. The Collaboration of Innovation Intermediaries and manufacturing firms in the markets for technology. Journal of Product Innovation Management 30: 142-158.

Macho-Stadler I, Perez-Castrillo D, Veugelers R. 2007. Licensing of University Inventions: The Role of a Technology Transfer Office. International Journal of Industrial Organization 25: 483-520.

Martiskainen M. 2016. The role of community leadership in the development of grassroots innovations. Environmental Innovation and Societal Transitions, in press.

Markard J, Raven R, Truffer B. 2012. Sustainability transitions: an emerging field of research and its prospects. Research Policy 41: 955-967.

Marvin S, Medd W. 2004. Sustainable infrastructure by proxy? Intermediation beyond the productionconsumption nexus. Sustainable consumption: the implications of changing infrastructures of. ed. / Dale Southerton; Heather Chappells; Bas Van Vliet. Cheltenham : Edward Elgar, 2004. p. 81-96.

Mattes J, Huber A, Koersen J. 2015. Energy transitions in small-scale regions - What we can learn from a regional innovation systems perspective. Energy Policy 78: 255-264.

Meyer M. 2010. The rise of the knowledge broker. Science Communication 32 : 118-127.

Moore M-L, Westley F, Broadhead T. 2012. Social Finance Intermediaries and Social Innovation. Journal of Social Entrepreneurship 3(2): 185-205.

Moss T. 2009. Intermediaries and the governance of sociotechnical networks in transition. Environment and Planning A 41: 1480-1495.

Nielsen K.H. 2016. How user assemblage matters: Constructing learning by using in the case of wind turbine technology in Denmark, 1973-1990. In Hyysalo, S. Elgaard Jenssen, T. \& Oudshoorn, N The New Production of Users: Changing innovation collectives and involvement strategies. New York: Routledge: 101-125.

Orstavik F. 2014. Innovation as re-institutionalization: a case study of technological change in housebuilding in Norway. Construction management and economics 32(9): 857-873.

Parag Y, Janda K. 2014. More than filler: Middle actors and socio-technical change in the energy system from the "middle-out". Energy Research and Social Science 3: 102-112.

Petticrew M, Roberts H. 2006. Systematic Reviews in the Social Sciences: A Practical Guide. Malden, MA: Wiley-Blackwell.

Polzin F, von Flotow P, Klerkx L. 2016. Addressing barriers to eco-innovation: Exploring the finance mobilisation functions of institutional innovation intermediaries. Technological Forecasting and Social Change 103: 34-46. 
Rip A, Kemp R. 1998. Technological change. In S. Rayner \& E. L. Malone, eds. Human Choice and Climate Change: Volume 2: Resources and technology. Columbus, Ohio: Battelle Press, pp. 327399.

Rochracher H. 2009. Intermediaries and the governance of choice: the case of green electricity labelling. Environment and Planning A 41: 2014-2028.

Rosenbloom D, Berton H, Meadowcroft J. 2016. Framing the sun: A discursive approach to understanding multi-dimensional interactions within socio-technical transitions through the case of solar electricity in Ontario, Canada. Research Policy 45: 1275-1290.

Rotmans J, Kemp R, van Asselt M 2001. More evolution than revolution: transition management in public policy. Foresight 3: 15 - 31

Safarzynska K, Frenken K, van den Bergh J. 2012. Evolutionary theorizing and modeling of sustainability transitions. Research Policy 41(6): 1011-1024.

Schreuer A, Ornetzeder M, Rohracher H. 2010. Negotiating the local embedding of socio-technical experiments: a case study in fuel cell technology. Technology Analysis \& Strategic Management 22: 729-743.

Seyfang J, Hielscher S, Hargrieves T, Martiskainen M, Smith A. 2014. A grassroots sustainable energy niche? Reflections on community energy in the UK. Environmental Innovation and Societal Transitions 13: 21-44.

Smink M, Negro SO, Niesten E, Hekkert M. 2015. How mismatching institutional logics hinder nicheregime interaction and how boundary spanners intervene. Technological Forecasting and Social Change 100: 225-237.

Smith A. 2007. Translating Sustainabilities between Green Niches and Socio-Technical Regimes. Technology Analysis \& Strategic Management 19: 427 - 450.

Smith A, Raven R. 2012. What is protective space? Reconsidering niches in transitions to sustainability. Research Policy 41: 1025-1036.

Sternlieb F, Bixler RP, Huber-Stearns H, Huayhuaca C. 2013. A question of fit: Reflections on boundaries, organizations and social-ecological systems. Journal of Environmental Management 130: $117-125$.

Stewart J, Hyysalo S. 2008. Intermediaries, users and social learning in technological innovation. International Journal of Innovation Management 12: 295-325.

Tisenkopfs T, Kunda I, šūmane S, Brunori G, Klerkx L, Moschitz H. 2015. Learning and Innovation in Agriculture and Rural Development: The Use of the Concepts of Boundary Work and Boundary Objects. The Journal of Agricultural Education and Extension 21: 13-33.

Turnheim B, Geels F. 2012. Regime destabilisation as the flipside of energy transitions: lessons from the history of the British coal industry (1913-1997). Energy Policy 50, 35-49.

Turnheim B, Geels, FW., 2013. The destabilisation of existing regimes: confronting a multidimensional framework with a case study of the British coal industry (1913-1967). Research Policy 42: 1749-1767.

van Lente, H., Hekkert, M., Smits, R., van Waveren, B., 2003. Roles of systemic intermediaries in transition processes. International Journal of Innovation Management, 7, pp.247-279.

van Lente, H., Hekkert, M., Smits, R., \& van Waveren, B. 2011. Systemic intermediaries and transition processes, in Guy, S., Marvin, S., Medd, W. \& Moss, T. (Eds.) Shaping Urban Infrastructures: Intermediaries and the Governance of Socio-Technical Networks. London, Earthscan, 36-52. 
White R, Stirling A. 2015. Sustaining trajectories towards Sustainability: Dynamics and diversity in UK communal growing activities. Global Environmental Change 23(5): 838-846.

Wieczorek, A.J., Hekkert, M.P., 2012. Systemic instruments for systemic innovation problems: A framework for policy makers and innovation scholars. Science and Public Policy 39, 74-87.

Wihlborg E, Söderholm K. 2013. Mediators in action: Organizing sociotechnical system change. Technology in Society, 35(4), 267-275

Williams R, Slack R, Stewart J. 2005. Social Learning in Technological Innovation - Experimenting with Information and Communication Technologies. Cheltenham: Edgar Algar Publishing 


\section{Appendix A}

Theories used

Sector of empirical focus

Definition of intermediaries

Key focus on intermediaries (intentional, yes/no)

Use the term intermediary explicitly (yes/no)

Origin of intermediaries

Established to intermediate (yes / no / uncertain)

Assuming intermediary roles over time (yes / no / uncertain)

Changing intermediary roles over time (yes / no / uncertain)

Unaware they are intermediating (yes / no / uncertain)

Identity/emergence/position

Bridging what

Pre-development / exploration

Take-off

Embedding, fit-and-conform

Embedding Strech-and-transform

Destabilisation

Stabilisation

Scale (niche/regime)

Niche-regime focus

Niche activities (shielding/nurturing/empowering)

Regime activities (stretch-transform/fit-conform)

Scope of action (in time/in space or place)

Synergies/tensions and incoherences

Key observations regarding intermediaries

Insiders vs. outsiders

Neutrality vs. own gain 


\section{Recent papers in the SPRU Working Paper Series:}

\section{August}

Innovation, Inequality and the Skill Premium. Riccardo Leoncini

User-Intermediaries and the Local Embedding of Low Carbon Technologies. Jake Barnes

\section{July}

Who Gains from High-Tech Growth? High-Technology Multipliers, Employment and Wages in Britain. Neil Lee and Stephen Clarke

June

Measures, Drivers and Effects of Green Employment: Evidence from US Local Labor Markets, 2006-2014. Francesco Vona, Giovanni Marin and Davide Consoli

Structural Changes and Growth Regimes. Tommaso Ciarli, André Lorentz, Marco Valente and Maria Savona

Explaining Sociotechnical Transitions: A Critical Realist Perspective. Steve Sorrell

Social Innovation, Democracy and Makerspaces. Adrian Smith

Adoption and Diffusion of Micro-Grids in Italy. An Analysis of Regional Factors Using Agent-Based Modelling. Francesco Pasimeni

\section{May}

The Measurement of Synergy in Innovation Systems: Redundancy Generation in a Triple Helix of University-Industry-Government Relations. Loet Leydesdorff, Henry Etzkowitz, Inga Ivanova and Martin Meyer

\section{March}

Inclusive Innovation and Rapid Sociotechnical Transitions: The Case of Mobile Money in Kenya. Elsie Onsongo and Johan Schot

Does Managerial Experience Affect Strategic Change? Matte Hartog and Frank Neffke Coworker Complementarity. Frank Neffke

\section{Suggested citation:}

Paula Kivimaa, Wouter Boon, Sampsa Hyysalo and Laurens Klerkx (2017). Towards a Typology of Intermediaries in Transitions: a Systematic Review. SPRU Working Paper Series (SWPS), 2017-17: 1-27. ISSN 2057-6668. Available at: www.sussex.ac.uk/spru/swps2017-17

\section{SPRU - Science Policy Research Unit}

University of Sussex

Falmer, Brighton, BN1 9SL,United Kingdom

SWPS Website: www.sussex.ac.uk/spru/research/swps

SPRU Website: www.sussex.ac.uk/spru

SPRU Twitter: @SPRU 